\title{
TERPAAN MEDIA MASSA DAN TURBULENSI BUDAYA LOKAL
}

\author{
Dominikus Tulasi \\ Jurusan Marketing Communication, Fakultas Ekonomi dan Komunikasi, Universitas Bina Nusantara, \\ Jln. Kemanggisan Ilir III No. 45, Kemanggisan, Palmerah, Jakarta Barat \\ dtulasi@binus.edu
}

\begin{abstract}
The attack of mass media in digital era now is an inevitability of the advanced information communication technology. The development of media relation in the current time also shows a higher scientific human existence. And, the side effect of those advances is the ultimate culture turbulence across developing countries. The sophisticated information communication technology at the present time has been victimizing young generation particularly in under developed countries. The power of media is a matter of fact which showing the domination influence of advance nations. In the other hand, the local culture of the victimized countries though still exists, but ultimately is the overwhelmed market of the media goal itself. The hegemony of media influence is the objective of advanced countries to dominate all aspect of weak countries including Indonesia. The global dominanace of advance country like American media is often resented overseas.
\end{abstract}

Keywords: mass media, local culture

\begin{abstract}
ABSTRAK
Terpaan media masa di era 'digital' saat ini merupakan sebuah keniscayaan dari teknologi komunikasi informasi yang unggul. Perkembangan hubungan media masa kini juga menunjukkan existensi manusia ilmiah yang lebih unggul. Dan, pengaruh samping dari semua kemajuan dan keunggulan tersebut memuncak pada kekacauan budaya local khusussnya di Negara-negara berkembang. Kecanggihan teknologi komunikasi informasi saat ini telah mengarah pada degradasi budaya bagi generasi muda khusus di Negara-negara berkembang. Kekuatan media adalah kenyataan yang menunjukkan betapa kuatnya pengaruh Negara-negara maju khusus Amerika yang berpengaruh dominant. Dipihak lain, budaya local Negara berkembang meskipun masih 'ada', pada akhirnya menjadi tujuan pemasaran informasi dari Negara produsen media. Hegemoni pengaruh media merupakan tujuan dominasi Negara maju terhadap Negara berkembang termasuk Indonesia. Dominasi media global yang dimotori Amerika terhadap Negara berkembang nampak menimbulkan rasa benci terhadap Negara maju, oleh karena ketidakseimbangan distribusi informasi.
\end{abstract}

Kata kunci: media masa, budaya lokal 


\section{PENDAHULUAN}

Tatkala iPad mulai diperjualbelikan pada 3 April 2010, Steve Jobs, berseru dengan suara lantang:"It's going to be a game changer," (Rodman, 2011) inilah produk inovasi media baru yang mampu merubah seluruh struktur berfikir manusia di era interaktif ini. Dan benar, pernyataan Penemu iPad ini seketika itu merebak dan menggemparkan semua orang yang melek teknologi. Media massa yang mengakses informasi atas pernyataan Steve Jobs ini, mampu berperan menjalankan fungsinya menggugah dan menarik perhatian manusia sejagat. Semua orang, khususnya di Amerika yang menunggu penjualan perdana mampu bertahan berjam-jam dalam antrian yang sangat melelahkan, namun menyenangkan. Dalam kenyataannya hingga saat ini, kita menyaksikan bahwa iPad dan semua alat teknologi mobile lainnya, kemungkinan merupakan penemuan teknologi masa depan yang menggantikan media-media tradisional. Hal ini tidak terbatas hanya pada fungsinya bagaimana membaca berita dan buku-buku, menonton televisi, mendengarkan radio, melainkan juga merupakan suatu cara jitu manusia, untuk menyelami dan menjelajahi seluruh isi jagat ini, dengan cara menggabungkan semua "perangkat lunak" yang populer melalui cara yang mudah dan menyenangkan. Dalam menjalankan fungsinya media mobile ini membutuhkan media literacy dari manusia sebagai aktornya.

\section{METODE}

Penelitian menggunakan studi literatur, yaitu mencari informasi yang terkait dengan sejarah dan perkembangan media masa. Turbulensi informasi, dan budaya lokal.

\section{PEMBAHASAN}

\section{Arus Informasi dan Media Literacy}

Manusia yang mampu meng-analisis potensi dampak media termasuk iPad dalam evolusinya itulah inti dari melek media (media literacy). Media literacy adalah kemampuan manusia untuk menggunakan media secara produktif sekaligus memahami cakupannya. (Rodman, 2011). Melek media berarti memahami akibat media bagi masyarakat tentang bagaimana membedakan antara menjadi korban dan seketika juga mampu mengontrol pengaruhnya yang berdampak luas. Dan, dampak dari terpaan media mobile inilah yang kita sebut sebagai media massa futuristik, atau media massa untuk masa depan. Media massa merupakan istilah untuk menggambarkan suatu bentuk komunikasi yang dilakukan pengirim pesan lewat media yang bergerak satu arah kepada masyarakat umum.

Media massa dikategorikan sebagai alat dan instrumen komunikasi yang memungkinkan kita merekam serta mengirim informasi dan pengalaman-pengalaman dengan cepat kepada khalayak luas yang terpencar-pencar dan heterogen. Media massa dengan dukungan teknologi mobile saat ini telah membantu meniadakan jarak antara yang makrososial dan mikrososial. Media massa membawakan tema-tema publik ke dalam lingkungan privat. Sebaliknya, lingkungan privat juga mudah memasuki lingkungan publik. Antara lingkungan publik dan lingkungan privat saling memasuki tanpa ada yang mampu membatasinya. Hal ini sangat tergantung kepada manusia sebagai aktor media literacy tentang bagaimana menggunakannya.

Saat media massa mobile memasuki dan dimasuki, sangat dipengaruhi oleh kondisi, orientasi, otoritas dan kebiasaan-kebiasaan aktornya sebagai human being. Momen dimana manusia sebagai aktornya tak membatasi kehendaknya itulah terobosan negatif yang mampu menghancurkan adat- 
istiadat, tradisi dan warisan budaya lokal yang terdampar dari aslinya. Contohnya, perhatian kaum muda khusus juga daerah pedesaan, sudah sangat terkontaminasi dengan budaya luar akibat mudahnya mengakses informasi lewat internet, tanpa menghiraukan nilai-nilai lokal yang luhur dan baik. Thomson seorang pakar komunikasi menyatakan: dunia publik telah dimediakan dan dibangun kembali di era elektronik ini, baik secara teknologis, maupun secara sosial (Lull, 2007).

Media massa dengan paduan komputer dan telekomunikasi menghasilkan gelombang informasi dengan kecepatan cahaya kepada khalayak yang jumlahnya sangat banyak. Media massa bertugas menyalurkan berita berupa simbol-simbol dan untaian kata-kata dalam kalimat yang baik dan buruk, yang benar dan yang salah, terus mendampar ke seluruh pelosok dunia ini. Teknologi komunikasi yang telah menciptakan "jalan bebas hambatan" (McLuhan), tidak hanya mencipatkan globalisasi ekonomi, namun juga mengaburkan batas-batas negara serta sosial budaya, karena, kedaualatan penyebaran informasi mendominasi dunia yang sedang kita bangun tidak mungkin dibatasi. Informasi dan salurannya meliputi langit bebas, yang merupakan milik bersama. Budaya, sebagai salah satu produk manusia yang menjadi identitas sosialnya dalam sebuah masyarakat, tidak luput dari pengaruh media massa. Budaya semakin tersobek dan terhempas dari aslinya. Kehadiran media massa dan pengaruhnya terhadap eksistensi budaya lokal sudah tidak terbendung. Dengan kata lain, budaya lokal mengalami alienasi, disudutkan dan tersudut.

\section{Media Massa dan Turbulensi Budaya Lokal}

Dalam kehidupan kita, kehadiran media massa sudah bukan hal yang asing. Alat komunikasi seperti: televisi, radio, koran, film adalah hal biasa. Media sosial di internet justru menjadi perhatian utama, dan sudah menjadi media yang sangat digandrungi sebagian terbesar anak muda. Bahkan orang tuapun ikut terperosok kedalamnya. Apabila pemanfaatannya bernilai produktif, maka teknologi komunikasi menjadi sangat berguna bagi kehidupan manusia. Namun, jika sebaliknya, maka nilai-nilai negatif yang akan menerpa kehidupan kita. Ketakutan akan turbulensi budaya diberbagai belahan dunia bukan tanpa alasan. Menurut survei 'The Pew Research Center tahun 2002' bahwa hegemoni budaya yang didominasi Amerika Serikat melahirkan antipati dan sentimen terhadap Amerika; misalnya, Perancis 58 persen, Argentina 78 persen, dan Turkey 88 persen, Indonesia bereaksi lebih radikal dengan berbagai demo dan spanduk yang bertuliskan: protes terhadap media-media Amerika seperti majalah Playboy (dalam Rodman, 2011). Media massa umumnya menggunakan konfigurasi teknologi; sifatnya formal atau non-formal dan dioperasikan berdasarkan ketentuan hukum yang belum final penafsirannya. Dalam operasionalnya, media massa diterbitkan dan disiarkan oleh kelompok yang bertujuan untuk menyampaikan informasi, hiburan, pikiran dan simbol-simbol yang dianggap bermanfaat bagi khalayak banyak. Kebebasan individulah yang akan menentukan batasanbatasan dan norma-norma yang layak bagi diri sendiri dan masyarakat umumnya.

Pada saat ini, suka atau tidak suka, media massa sebenarnya telah mengkonstruksi realitas baru kepada khalayak, dan kita sudah tercebur berjalan diatas dataran realitas itu. Media massa, selain dipengaruhi oleh pemerintah dengan orientasi politik, pengaruh undang-undang yang berlaku, sesungguhnya pengaruh pemilik modal dan para professional media jauh lebih mendominasi. Wajar saja, para pakar menyatakan bahwa media massa adalah hegemoni baru negara-negara maju terhadap dunia berkembang.

Pertumbuhan media massa menandai kemajuan peradaban manusia modern, oleh karenanya, Rogers (dalam Rodman) membagi perkembangan komunikasi manusia menjadi empat era, yakni: era komunikasi tulisan, era komunikasi cetak, era telekomunikasi dan era komunikasi interaktif. Bila dalam era komunikasi tulisan, perkembangan informasi mungkin dengan kelipatan 5 untuk periode tertentu, hal itu sangat berbeda jauh di saat manusia memasuki era komunikasi interaktif dengan frekwensi yang bertalu-talu dan tak terbatas. Deskripsi diatas menjadi wajar, bila media massa akhirnya menjadi kebutuhan sehari-hari bagi manusia. Pertanyaan dasarnya adalah, apakah media 
massa membentuk budaya baru atau hanya sebatas mempengaruhi perubahan budaya-budaya yang ada? Bila berpengaruh, bagaimana bentuk budaya baru yang dihasilkan media massa?

\section{Konstruksi Budaya Asing dan Budaya Lokal}

Ketika membahas tentang budaya dan kebudayaan, maka yang terbayang adalah sebuah rangkaian totalitas yang mencakup keseluruhan perilaku dan aktivitas manusia. Dengan kata lain, budaya dan kebudayaan adalah produk sekaligus proses membudaya itu sendiri. Edward Tylor (dalam Rodman, 2011) menyatakan: kebudayaan sebagai kompleksitas keseluruhan yang meliputi kepercayaan, moral, hukum dan kemampuan lainnya termasuk kebiasaan yang didapatkan dari anggota masyarakatnya. Konsep ini ditransmisikan secara sosial dan mendapatkan justifikasi atas intervensi budaya luar yang masuk karena kemajuan teknologi informasi canggih. Dominasi dan hegemoni atas media massa tak terkontrol. Yang terjadi kemudian adalah 'cultural imperialism' seperti yang kita saksikan di era digital ini. Berbahayakah budaya asing? Budaya, walaupun kelihatannya rumit karena menyangkut nilai yang diyakini sekelompok orang tertentu, tetapi kebudayaan tetap bergerak secara dinamis kearah pergeseran dan perubahan. Pandangan ini disebabkan oleh makin terbukanya masyarakat di era interaktif ini. Hampir tidak ada satupun bangsa di dunia yang tidak pernah berinteraksi dengan budaya asing lainnya. Pertanyaannya adalah apa manfaat melarang masuknya budaya asing? Masih mampukah atau mampukah kita melarang budaya luar?

Indonesia menurut hemat saya, tingkat akomodasi dan akseptasi terhadap produk budaya asing khususnya transfer budaya pop dari Amerika merupakan sebuah keniscayaan yang tak mungkin dibendung. Model transfer budaya Amerika ini dapat berlangsung secara eksplisit maupun implisit. Eksplisit misalnya, di Amerika diselenggarakan 'American Idol' maka di Indonesia-pun diadakan 'Indonesian Idol'. Acara ini adalah copy paste penyelenggaraan sebuah acara. Bahkan termasuk produksi seni dan acara-acara spektakuler lainnya. Maka menjadi aneh jika kemudian ada sekelompok masyarakat yang baru terkejut untuk membendung budaya Amerika. Pelarangan beberapa artis Amerika ataupun artis negara lain ke Indonesia untuk melakukan 'show' adalah wujud sebuah kemunafikan yang terlambat dilakukan. Termasuk dalam hal ini pelarangan terhadap Lady Gaga yang hendak melakukan konser di Indonesia. Akibatnya, Indonesia sebagai negara demokratis dilihat sebagai “monster” yang menakutkan, dan implikasinya membungkam kreativitas seni Indonesia.

Menurut hemat saya, Indonesia adalah negara yang “amburadul” dalam menyikapi peradaban dan keterbukaan. Acuan dasar dalam bersikap tidak jelas. Antara norma dan kenyataan jaraknya sangat "terjal". Istilah menjaga moral bangsa dari pengaruh asing adalah sebuah pernyataan 'tanpa makna'. Coba tengok pertunjukkan budaya kita yang digolongkan budaya asli seperti 'dangdut hot atau dangdut koplo, tarian ronggeng' yang diselenggarakan berbalut istilah saweran. Saweran adalah sebuah istilah masyarakat lokal untuk menghamburkan uang ketika sang 'pedangdut' wanita meliukkan tubuhnya di atas panggung hiburan. Menurut pengamatan saya, pertunjukkan dangdut seperti itu, jauh lebih 'porno' aksi. Goyangan pinggul pedangdut jauh lebih menggoda dan merendahkan martabat wanita dari bangsa yang munafik dan bertopeng kata 'menjaga moral'. Tak disebutkan nama pedangdut lokal, namun perhelatan dangdut kampung adalah pertunjukkan 'mesum' yang dibalut dengan istilah 'saweran'. Perhatikan 'tayuban, tarian ronggeng, adalah pertunjukan untuk memuaskan 'mata' kaum lelaki. Semuanya adalah ciptaan kaum lelaki yang sudah sejak lama mendominasi kaum wanita di negeri ini. Dominasi kaum lelaki dibiarkan berkembang, sementara kaum wanita 'dipaksa' membatasi pergaulannya demi kepuasan kaum lelaki. Wanita diatur kehidupannya seperti makhluk ternak, sementara kaum lelaki boleh melakukan apa saja, dan pelabelannya selalu positif atau dipositifkan. Coba renungkan kosa kata yang dilabelkan untuk kaum wanita "Pelacur". Jarang kata itu dikonotasikan untuk kaum maskulin. Padahal, "pelacur" hanya mungkin menawarkan diri apabila ada permintaan dari kaum lelaki yang bebas label negatif. 
Dari perspektif ekonomi, hadirnya penawaran, karena adanya permintaan. Dari sudut pandang ini faktor penyebabnya adalah permintaan yakni untuk memenuhi 'kebutuhan' kaum lelaki. Pertanyaannya mengapa kebiasaan ini dibiarkan berkembang dan bertumbuh sebagai nilai positif dalam masyarakat? Hemat saya, kita adalah bangsa maskulin yang dibiarkan bertumbuh menjadi nilainilai maskulin. Pertanyaannya adalah kemana saja para penjaga moral bangsa, sehingga tidak juga menghentikan atau melarang pertunjukkan 'dangdut saweran? Dan, masih banyak lagi pertunjukkan lain yang tak kalah hebohnya di negeri ini, dibandingkan 'show' orang asing yang jauh lebih profesional melihat ekspresi karya seni.

Jiwa kita mati rasa seni bergerak (moving art) bahkan rasa kita juga mati terhadap seni visual (visual art), yang semuanya dikategorikan 'porno'. Ukuran porno itu apa, dan bagaimana cara melarang generasi muda? Masuknya budaya atau kebiasaan asing yang sesungguhnya kita juga lakukkan secara eksplisit maupun implisit sulit dibendung. Jika pelarangan dilakukan untuk pertunjukkan di panggung terbuka, maka individu-individu manusia Indonesia dapat menyaksikan pertunjukkan seni asing apapun, di dalam kamar masing-masing. Kecanggihan teknologi informasi saat ini bisa dan dapat menemani kita kapan saja dan dimanapun. Tak ada ruang sedikitpun untuk membatasi penetrasi budaya luar. Sensor yang asli dan membumi menurut hemat saya adalah menanamkan nilai-nilai yang baik dan luhur di dalam keluarga msing-masing, dengan catatan berikan kebebasan berekspresi bagi manusia Indonesia untuk menikmati seni dan budaya apapun termasuk budaya dari luar. Kita akan menjadi manusia yang kuat dan kreatif apabila telah menyaksikan budaya orang. Pengaruh negatif akan tersingkir dan disingkirkan oleh masing-masing individu.

Orang Indonesia yang bertopeng ajaran moral, kehidupan domestiknya jauh lebih parah. Nilainilai yang kita miliki sejak ratusan tahun tak juga beranjak maju. Kurang terbuka, mau hidup enak tapi malas, menyimpan rasa iri, merelatifkan nilai yang menguntungkan diri atau kelompoknya. Tidak mau belajar dari budaya dan nilai-nilai hebat yang ada di negara lain. Jepang misalnya, budaya kerja keras adalah warisan nilai luhur bangsanya yang tidak pernah dibicarakan dan dikotbahkan, namun membara dan terus membakar jiwa generasi mudanya secara turun-temurun. Kita hanya bisa mampu mengklaim untuk menutupi kemunafikan sebagai bangsa yang ‘korup’. Mega korupsi yang meraja-lela berjalan tak tersentuh, dibiarkan merasuk kedalam sukma dan sendi-sendi kehidupan. Sebaliknya, kita sangat peduli terhadap kasus-kasus yang berbau sex atau yang digolongkan porno oleh para "penjaga" moral bangsa.

Satu kepastian yang sifatnya perenial dan tak mungkin dibendung adalah perubahan. Perubahan terjadi disegala aspek kehidupan, termasuk perubahan kebudayaan. Kebudayaan dari waktu ke waktu mengalami pergeseran nilai, seperti yang diperkenalkan Koentjaraningrat, bahwa kebudayaan dapat berubah atau bergeser, juga disebakan oleh proses internalisasi, sosialisasi dan enkulturasi sebagai wujud evolusi kebudayaan. Proses penyebaran kebudayaan secara geografis; terbawa oleh perpindahan bangsa-bangsa di bumi, yakni proses difusi; proses belajar unsur-unsur kebudayaan asing oleh masyarakat, yakni proses akulturasi dan proses asimilasi; serta proses inovasi dan penemuan baru.

Konsep internalisasi, adalah proses belajar kebudayaan yang panjang sejak individu dilahirkan sampai ia meninggal. Ia belajar menanamkan dalam kepribadiannya segala perasaan, hasrat, nafsu dan emosi yang diperlukan sepanjang hidupnya. Sedangkan, sosialisasi adalah suatu proses dimana seorang individu sejak masa kanak-kanak hingga masa tuanya belajar pola-pola tindakan dalam interaksi dengan berbagai macam individu di sekelilingnya yang menduduki berbagai peran sosial yang mungkin ada dalam kehidupan sehari-hari.

Proses enkulturasi atau proses pembudayaan, adalah proses seorang individu mempelajari dan menyesuaikan alam pikiran serta sikapnya dengan adat-istiadat, sistem norma, dan peraturan-peraturan yang hidup dalam kebudayaannya. Dan, proses evolusi kebudayaan, adalah proses perubahan 
kebudayaan bila dilihat dalam interval waktu yang panjang, akan terlihat perubahan-perubahan besar dalam kebudayaan.

Proses difusi kebudayaan, disebabkan oleh proses migrasi kelompok-kelompok manusia di bumi. Dengan migrasi tersebut, tersebar pula unsur kebudayaan di penjuru dunia, yang disebut difusi. Sedangkan akulturasi, atau acculturation atau culture contact adalah proses sosial yang timbul bila suatu kelompok manusia dalam suatu kebudayaan tertentu dihadapkan dengan unsur kebudayaan asing. Lambat laun, unsur kebudayaan asing itu diterima dan diolah dalam kebudayaan sendiri tanpa menyebabkan hilangnya kepribadian kebudayaan itu sendiri.

Asimilasi adalah proses sosial, yang timbul manakala, pertama, terdapat kelompok-kelompok manusia yang berbeda-beda; kedua, saling bergaul secara intensif untuk waktu yang lama, sehingga ketiga, kebudayaan golongan-golongan tadi masing-masing berubah sifatnya yang khas, dan unsurnya masing-masing berubah wujudnya menjadi kebudayaan campuran.

Lull, menggunakan teori perubahan kebudayaan dengan teori meme. Jika gerak dalam fisika selama ini dapat dijelaskan dengan atom atau partikel, evolusi dengan gene, maka perubahan sosial dengan meme. Istilah meme pertama kali diperkenalkan oleh Richard Dawkins. Menurut pengakuannya, istilah ini muncul karena Dawkins menganggap teori Darwin terlalu luas untuk hanya dibatasi pada peranan gene. Teori Evolusi Darwin dapat juga mencakup evolusi di luar biologi, seperti bahasa dan sosial budaya. Jadi, bila gene berperan dalam evolusi biologis, maka meme berperan dalam evelusi sosial budaya. Dua-duanya berfungsi sebagai pengganda diri sendiri (replicator).

Jika gene diketahui bersifat mementingkan diri sendiri (selfish), maka hampir pasti demikian juga dengan meme. Meme sebagai unit perubahan sosial budaya, bergerak mengejar suksesnya sendiri. Sukses meme terdiri dari tiga hal, yaitu usia yang panjangnya (longevity), tersebar seluasluasnya (fecundity), dan berketurunan seasli-aslinya (copying fidelity). Dawkins mendefinisikan meme sebagai segala hal yang dapat berpindah-pindahdari satu benak ke benak lain.

Pengembangan teori ini juga dilakukan oleh Richard Bordie, dalam Virus of Mind: The New Service of the Meme (1976). Menurut Bordie, meme adalah suatu unit informasi yang tersimpan dalam benak seseorang, yang mempengaruhi kejadian di lingkungannya sedemikian rupa sehingga makin tersebar luar ke benak orang lain.

Bordie membagi semua meme ke dalam tiga jenis: distinction meme, strategy meme, dan association meme. Pada hakekatnya, peranan meme adalah: meme dapat berkembang untuk mewujudkan tri-suksesnya sendiri, tanpa menghiraukan kepentingan manusia yang dimanfaatkan. Inilah yang dapat dijelaskan, mengapa siaran kekerasan misalnya, terus saja diproduksi dan dinikmati, kendati setiap orang mengetahui bahayanya.

Terdapat tiga jalur utama yang digunakan meme untuk menulari benak manusia: pengulangan (repetition); ketegangan (cognitive dissonance) dan menanggulangi (free riding). Iklan, dikategorikan sebagai repetition; beberapa pengertian yang mengganggu ketenangan hati termasuk cognitive dissonance dan segala gagasan yang menunggangi naluri manusia, seperti lapar, sex, dan mempertahankan diri, termasuk free riding.

\section{Budaya Elit vs Budaya Marginal}

Harold Innis dan Marshal Mcluhan adalah sarjana modern pertama yang mengkaji hubungan antara alat komunikasi yang terdapat didalam masyarakat dan bagaimana alat komunikasi itu berperan dalam membentuk karakter serta bidang sosial mereka, seperti bidang ekonomi, politik dan sosial budaya. 
Mcluhan yang banyak belajar dari Innis, mengembangkan ide itu pada periode modern. Ia mulai melihat bahwa pengaruh sistem percetakan dapat menyebarkan ide-ide serta pengetahuan. Ini terlihat, saat Guttenberg (1450) menemukan huruf cetak yang dapat dipindah-pindahkan, secara langsung memacu percetakan buku di Eropa.

Dari kenyataan ini, Mcluhan mengatakan bahwa media elektronik modern, khususnya radio, televisi, photografi dan film dapat membentuk pola pikir masyarakat modern. Ide itu berpengaruh di Amerika Utara dan Eropa. Apa yang dilakukan media terhadap implikasinya secara global; ia membuat sesuatu yang pertama kali dalam sejarah kemungkinannya sistem informasi yang cepat (instant) antara sejumlah titik di dunia yang disebut Mcluhan sebagai "the global village".

Serupa dengan pendapat Koentjaraningrat bahwa fenomena percepatan transformasi ide disebut difusi, di mana unsur kebudayaan yang timbul di salah satu tempat di muka bumi, berlangsung dengan cepat sekali, bahkan sering kali tanpa kontak antar individu. Ini disebabkan karena adanya alat penyiaran yang efektif seperti surat-kabar, majalah, buku, radio, film, dan televisi.

Pertemuan budaya dan proses mempelajari budaya yang diakibatkan oleh media komunikasi massa, disebabkan juga oleh banyaknya waktu yang digunakan manusia untuk berinteraksi dengan media massa.

Mcluhan, dengan mengembangkan ide Innis menghasilkan simpulan bahwa media adalah perpanjangan alat indra manusia. Dengan media massa, orang dapat memperoleh informasi tentang beda, orang atau tempat, dengan tidak mengalami secara langsung. Dengan media itu pula, manusia dapat mengembangkan pola pikir dan perilaku mereka.

Bentuk perubahan budaya, Stan Le Roy Wilson membagi tahapan perkembangan budaya pada: pertama, tahap Elitis, budaya ini hanya nampak di masa lalu ketika budaya masih dibedakan dalam kategori budaya elit (elite culture), yakni budaya orang terdidik, aristocrat dan orang kaya. Budaya elit kadang-kadang dikategorisasi sebagai budaya tinggi (high culture). Hingga kurang dari 200 tahun yang lalu, terdapat perbedaan antara high culture dan yang lainnya kelas petani, yang dikenal dengan budaya rakyat jelata.

Kelas Elit, adalah orang-orang yang hidupnya dikelilingi seni, buku, dan musik klasik. Para petani dengan budaya rakyat, berhubungan langsung dengan Carnaval di jalan-jalan, kedai minum, lagu-lagu dan dongeng-dongeng rakyat.

\section{Budaya Populer}

Pada abad ke-19, perbedaan antara budaya elit dan budaya rakyat semakin kabur dengan dibangunnya demokrasi politik, pendidikan masyarakat massa dan Revolusi industri. Kekuatan ini menciptakan budaya popular dan budaya massa.

Budaya Populer, didefinisikan Ray B. Brown sebagai, "The cultural world around us. Our attitudes, habits and actions: how we act, why we act. What we act, buildings, roads and means to travel our entertainment, spots, our politics, religion, medical practices, our beliefs and activities and what shapes and control them. It is, in the other words, to us what waves is to fish; it is the worlds we live in?”

Penggunaan istilah budaya popular dalam kajian Stan Le Roy Wilson, dilukiskan dengan apa yang mengelilingi kehidupan kita setiap hari. Budaya popular adalah budaya yang dengannya kita berpedoman dalam berbusana. Mode, dan seluruh kegiatan yang kita lakukan (Fiske, 1989, understanding popular culture). 
Budaya popular juga disebut budaya massa, dimungkinkan oleh kombinasi dari teknologi industri dan ekonomi, memasuki produksi massa budaya untuk sejumlah besar audiens. Budaya yang dipelihara sejak lama oleh orang-orang terpelajar dan orang-orang elit yang kaya, menjadi produk budaya missal lewat buku-buku, surat-surat kabar, majalah-majalah, rekaman-rekaman, CDs, bioskop, radio dan media massa lainnya. Karena menurut Staubhaar industrialisasi media pada dasarnya mendorong terciptanya budaya massa.

Dalam pandangan Paul Willis, media massa adalah media budaya. Karena media massa mengimplikasikan bahwa sumber "menghasilkan secara massal" pesan-pesan yang akan dikirim kepada "khalayak massa" yang dalam benak sejumlah kritikus, telah membantu menciptakan "budaya massa” yang lebih rendah mutunya.

Kekuatan media massa yang besar dalam mentransformasikan pesan-pesan ini, sehingga tidak berlebihan, bila Mcluhan menyebut "the medium is the message”, (Fiske, 1989).

\section{Tahap Spesialisasi}

Tahap spesialisasi dimulai di akhir abad 20, di mana banyak sekali terobosan media massa Amerika Serikat dalam mencapai tahap ini. Tahap ini digambarkan futurolog Alfin Tofler sebagai “demassifikasi media massa”. Pada tingkatan ini, media massa dikonsumsi sepotong-sepotong oleh populasi, tiap-tiap orang dengan ketertarikan dan aktivitas budaya sendiri. Kondisi ini dimungkinkan dngan banyaknya pilihan masyarakat terhadap media. Untuk televisi, misalnya, orang dapat memilih program yang disenangi, dengan menekan saja remote kontrol. Namun, dalam kategorisasi, Negaranegara yang belum mencapai tahap perkembangan seperti Negara Amerika Serikat, tahapannya masih berada pada tahap popular (Thomson, 2005).

Bentuk lain dari perubahan budaya yang diakibatkan oleh media massa adalah bahwa media massa menciptakan imperialisasi budaya dan kekuasaan budaya (Joseph Staubhaar). Menurut Lull, hal ini dimungkinkan karena media massa dewasa ini mudah menerobos batas-batas nasional dan budaya. Dampaknya adalah, kekuatan Barat yang dimotori oleh perusahaan-perusahaan transnasional Amerika, telah memonopoli komunikasi dunia, sampai sedemikian rupa, sehingga amat merugikan kesejahteraan dan identitas bangsa-bangsa yang kalah kuat.

Monopoli ini dimungkinkan dari negara kuat terhadap negara yang kalah kuat, antara lain juga disebabkan oleh minimnya subsidi dari pemerintah setempat untuk program siaran televisi. Solusi dari masalah ini adalah negara tersebut mengimpor siaran dengan harga yang lebih murah dibanding memproduksi sendiri, dan jadilah film seperti Betti La Fea misalnya, dikonsumsi hampir diseluruh dunia.

Dominasi budaya yang digambarkan Lull, bahwa penjualan "budaya pop” dengan cepat menjadi sebuah industri besar, terutama di Amerika Serikat. Menjelang pertengahan dasawarsa 1990an ketika kemajuan teknologi melaju dengan cepat, perusahaan transnasional kembali memperoleh keuntungan paling banyak secara materi dengan meningkatnya kapasitas untuk enghimpun, menyimpan, mengelolah, dan mengirim informasi. Korporasi transnasional melahap semua saluran satelit, komputer mainframe yang kuat, dan konfigurasi multimedia hingga mesin faksimili, system surat suara dan telepon mobil. Dan dengan menggunakan teknologi komunikasi tercanggih, perusahaan transnasional memonopoli arus informasi internasional, mengkolonikan kebudayaan Dunia Ketiga dengan cara itu.

Peran media masa dalam perubahan budaya, dijelaskan selanjutnya oleh Lull, sebagai proses transkulturasi, hibridasi dan pribumisasi. Transkulturasi, mengacu pada sebuah proses secara harafiah bergerak melalui ruang dan waktu untuk berinteraksi dengan kebudayaan lain, saling mempengaruhi 
dan menghasilkan bentuk budaya baru. Proses transkulturasi dihasilkan oleh perpindahan fisik orangorang dari satu lokasi geografis ke lokasi geografis lainnya. Tetapi kini, pelintasan budaya lebih banyak dimungkinkan oleh media massa dan industri kebudayaan. Teknologi modern. Membangun kembali pemotong jarak budaya yang essensial, yakni ruang dan waktu. Dengan teknologi informasi, transmisi, penerimaan informasi dan hiburan dari satu bagian dunia ke bagian dunia lain menghasilkan sintesis-sintesis budaya baru.

Transkulturasi menghasilkan hibrida budaya yakni penyatuan (fusi) bentuk budaya. Bentuk dan genre hibrida menurut Lull dapat dikatakan pop. Pribumisasi, merupakan bagian dari hibrida. Pribumisasi berarti bahwa bentuk budaya impor menerima unsurlokal yang menonjol. Ini dapat terlihat misalnya pada jenis musik tertentu yang masuk ke Indonesia dan tampil sebagai jenis musik baru, misalnya musik rap, yang liriknya sudah mengacu pada kepribadian, kondisi, dan situasi lokal Indonesia.

\section{SIMPULAN}

Media massa, merupakan alat komunikasi yang digunakan untuk mengirim pesan massa, ditujukan kepada khalayak massa. Kehadiran media massa yang ditandai dengan ditemukannya huruf cetak yang dapat dipindah-pindahkan oleh Guttenberg, secara langsung berpengaruh di Eropa, dengan meningkatnya permintaan untuk mencetak buku. Percetakan buku dilanjutkan oleh media massa lain, yakni surat kabar, yang memicu urbanisasi pada masa revolusi industri. Pergeseran, pertukaran, dan asimilasi budaya berlangsung dalam proses ini. Perubahan budaya yang diakibatkan oleh media massa mecakup hampir semua sisi kehidupan manusia. Ini terjadi, disebabkan antaranya kekuatan jangkauan media, kemudahan memperoleh akses, dan semakin banyak masyarakat yang mampu mengakses informasi karena penurunan biaya media massa. Perubahan budaya mengarah pada budaya massa atau budaya popular, di mana hampir tidak ada lagi perbedaan antara budaya elit dan budaya rakyat. Perkembangan media massa juga menciptakan dominasi budaya. Dominasi dapat terjadi karena Negara-negara kuat dengan perusahaan transnasional, menguasai hampir seluruh penyiaran satelit, menciptkan sekaligus "menjual" budaya popular sebagai komoditas ekonomi dan social budaya, kepada Negara-negara berkembang termasuk Indonesia.

\section{DAFTAR PUSTAKA}

Anderson, J. A., \& Meyer, T. P. (1988). Mediated Communication, Newbury Park, CA: Sage Publications.

Fiske, J. (1989). Understanding popular culture. New York: Routledge.

Judith N. Martin \& Thomas K. Nakayama, (2007), Intercultural Communication In Contexts, $4^{\text {th }}$ ed. The McGraw-Hill Companies, Inc., New York, 10020.

Lull, James (1995). Media, Communication, Culture: A Global Approach. Cambridge, England: Polity Press (co-published in USA by Columbia University Press, 1995).

Lull, James (ed.) (1992). Popular Music and Communication (revised edition). Newbury Park, CA: Sage Publications. 
Lull, James (2000). Media, Communication, Culture: A Global Approach (revised edition). Cambridge, England: Polity Press (co-published in USA by Columbia University Press).

McLuhan, M. (1965)., Understanding Media. New York: New American Library.

Rodman (2011), Mass Media In A Changing World, History, Industry, Controversy, Fourth Edition, McGraw-Hill International Edition.

Straubhaar, Joseph (1997), Communications Media in the Information Society; International Thomson Publishing Inc.,

Tracey, M. (1988). Popular culture and the economics of global television.

Toffler, Alfin (1990). Powershift, New York: Bantam Books.

Thomson, A. (1993, May 8) Forget doing lunch—Hollywood, or E-mail. The New York Times, p. 83

Thomson, (2005), The Effectiveness of Mass Media Campaigns: Youth Substance Abuse. www.bibalex.org/supercourse/supercoursePPT/23011-24001/23951.ppt. 